INTERNATIONAL JOURNAL OF MULTIDISCIPLINARY RESEARCH AND ANALYSis

ISSN(print): 2643-9840, ISSN(online): 2643-9875

Volume 04 Issue 12 December 2021

DOI: 10.47191/ijmra/v4-i12-02, Impact Factor: 6.072

Page No.- $1777-1788$

\title{
Flood Risk Management and its Compliance in Loko Community Adamawa State, Nigeria
}

\author{
Ndagana lyami Hadiza ${ }^{1}$, Felix Lamech Mogambi Ming'ate ${ }^{2}$, Samuel O. Ochola ${ }^{3}$ \\ ${ }^{1,2,3}$ Department of Environmental Studies and Community Development, School of Environmental Studies, Kenyatta University
}

\begin{abstract}
Flood risk management functions to reduce socio-economic and human resources associated with disasters. This study investigates flood risk administration for the socio-demographic progress of the Loko Community in the Song local government area in Adamawa State, Nigeria. The study's objective was to evaluate the compliance levels to flood risk management practices, challenges and interventions adopted to address the concerns. The study utilized a case study research design while targeting a population of 4,200 inhabitants comprising, 800 households, 20 NEMA staff and 40 ADSEMA staff. The findings indicated that floods significantly affects the socio-economic condition and livelihoods of the people. Moreover, the study found that institutional, cultural, and demographic factors limited compliance to FRM practices, necessitating the adoption of appropriate interventions. Therefore, it is necessary because homes far from flood-prone areas will mitigate the adverse flood effects. Similarly, the Ministry of Agriculture and Cooperatives through the Extension Services should incentivize the communities through funding to increase the area cultivated on the upland to enhance the food security at the household level. There should be increased support programmes for the affected, and viable farmers prioritized for the support programmes. The study concludes that there is a need to develop better and appropriate measures to prepare and mitigate the effects of floods. Socio-economic problems such as poverty, livelihood profile, cultural views, the position of weaker social groups, and the rights of minorities and ethnic groups must be addressed urgently.
\end{abstract}

KEYWORDS: Flood Risk Management, Floods, Community Perceptions and Attitudes, behaviour, mitigation measures, compliance, Flood Disaster Management, poverty, Socio-Demographic Characteristics.

\section{INTRODUCTION}

Flood risk management functions to reduce socio-demographic and human resources associated with disasters. Even though floods have their benefits particularly in the agricultural sector, their associated consequences can result in significant sociodemographic losses that result in long-term negative impact on the affected community (Morrison et. al., 2018). Flood Risk Management (FRM) focuses on analysing relationships between socio-demographic environment, physical systems and the institutional frameworks in place (Idris \& Dharmasiri, 2015).

Evidences indicate that occurrence of natural disasters in many countries has been on the increase, mainly due to environmental degradation (World Bank 2002; Loayza, et. al., 2012; World Bank, 2017). Africa is prone to many disasters which have resulted in significant negative socio-demographic impacts on the affected countries. Issues like lack of inadequate funding, high levels of poverty, inadequate disaster management expertise have led to poor disaster preparedness and poor response to disasters (Van Niekerk, 2015). Inadequate funding for disaster management in Africa leads to other secondary problems including stunted sociodemographic progress since affected people have to start afresh from statuses far below where they were before the disaster occurrence.

\section{A. Objectives and Structure of the Paper}

Nigeria's National Emergency Management Agency (NEMA) was formed by Act 12 of 1999, as modified by Act 50 of 1999 suggests mechanisms for funding post-disaster recovery measures and rehabilitation of affected areas and communities. It also mandates the creation of a disaster management strategy in the individual states and be a key part of their development plans (NEMA, 2012). NEMA also formulated the disaster management plan to highlight approaches to be used in reducing vulnerability of people in disaster prone areas together with measures to prevent and mitigate the flooding disasters. "Nigeria Vision 20:20:20" mentions, very briefly, disaster emergency needs and made no mention of FRM or disaster prevention. 


\section{Flood Risk Management and its Compliance in Loko Community Adamawa State, Nigeria}

Although NEMA is putting in a lot of work, disaster risk management has yet to be recognized as a national priority, and decisionmakers lack or have limited knowledge of disaster reduction concerns. Most of the flood risk interventions made at the three levels of government are responsive in that they focus on helping affected communities cope with the disaster by providing them with emergency services such as make-shift housing, food and medical supply. Nigeria currently does not have an effective flood risk management framework since more of the interventions are curative and not preventive, a factor that negatively affects communities in flood prone areas.

A true measure of socio-economic development is critical in advising the relevant authorities responsible for flood risk management to make informed decisions regarding the need to adopt interventions that will be sustainable in mitigating the impact on flooding on communities, especially Loko which this study focuses on. There are limited studies that asses the sociodemographic impacts of flood risk management. The paper sought to fill the knowledge gap by focusing on evaluating compliance to FRM practices in Loko community, including the challenges, and stakeholder interventions to address the situation. In such a case, the results from the numerous and relevant studies is critically examined and organised based on core concepts regarding the FRM benefits to communities affected by flood. Besides, the findings have been used to discuss empirical outcomes from the primary study to identify ambiguities, concurring and conflicting viewpoints, and knowledge gaps. The subsequent sections comprise the methodologies, results, discussion, conclusions, and recommendations aligning with the research problem.

The study was based on empowerment theory postulated by Zimmerman (2000). According to this theory, the development of proficiencies and capabilities contributes to the improvement of self-definition and personal growth among beneficiary community members. It also argues that a combination of personal effort, development and the existence of natural or man-made support structures is the product of change. The theory is largely focused on the premise that recipients have individual capacities that they can use to socially and economically construct themselves and thus only need to be provided with a forum that they can use to achieve their objectives. Empowerment is an evolving process that reflects on the environment and requires all stakeholders' awareness of the underlying problems (Kenny, 2016).

In addition, it is a collaborative process that requires fair involvement by all stakeholders, but focuses on increasing acceptance by the recipients. The primary beneficiaries who need a voice to help mitigate the effects of flooding on their livelihoods are Loko community members. Both the community and the local government at large know that flooding is the community's greatest issue, so services such as flood risk control help to alleviate the problem. Based on the empowerment theory, alleviating the flooding hazard would encourage members of Loko community to participate in socio-demographic activities that will empower them to improve their living standards.

\section{B. Socio-demographic characteristics of Disaster Prone Communities}

Damage to the available infrastructure, food supply and other economic systems is key evidence of disasters in a region (Lal, et. al., 2009). In a similar study, Mata-Lima et. al., (2013) also noted that the destruction of available primary and supportive resources contributes to a decline in income levels that ultimately lead to poverty. Poverty is a serious social issue that limits an individual's economic reach to basic things like food, quality healthcare and education for children. Consequently, this inhibits the willingness of affected people to contribute positively to the community's social growth. Study results from Mata-Lima et. al., (2013) further suggested that poverty is due to high unemployment structures in disaster-prone areas because certain economic systems such as businesses cannot work under flooded conditions. Despite giving an in-depth viewpoint on how disasters lead to poverty among community members, they have generalized that despite variations in the form of harm they cause, all kinds of disasters contribute to poverty in the same way.

Tirivangasi, (2018) undertook a study to investigate the influence of disaster risk management on food security. Findings indicated that disaster destroyed available food stocks, crops in the field and destroys infrastructure such as roads necessary to ensuring supply of food to disaster prone areas. According to the study, the destruction of food and available systems that influences its supply contribute to the occurrence of hunger which has other serious ramifications on the stability of families and the society. Ainehvand, et. al., (2019) added that disasters are a major challenge in achieving food security response measures as they destroy available systems meant to ensure food self-reliance. Nonetheless, the findings do not provide a detailed perspective regarding how specific disasters such as flooding contribute to hunger as a social problem.

However, it has been established that flooding causes severe effects on economic growth and promotes hunger, poverty and other social vices among many others (see Chapaign and Raizada, 2017; Jongman, 2018; Matemilola and Elegbede, 2017; Mwape, 2009; Olanrewaju et.al., 2019). To buttress the social effect of flooding in Nigeria, Aja and Olaore (2014) stated that due to increased precipitation connected with climate change and other human neglected activities, most states in Nigeria experience annual floods during the rainy seasons. As a result, floods are considered a danger to sustainability since they have a negative impact on the economy, social life, the environment, and human health (Ludwig et. al., 2007). In Nigeria, Echendu (2020) created 


\section{Flood Risk Management and its Compliance in Loko Community Adamawa State, Nigeria}

a clear link between floods and the Sustainable Development Goals (SDGs). This affirms that the social effect of flooding can promote poverty, food insecurity, loss of properties among many other aftermath experiences.

\section{Compliance to Disaster Risk Management Policies in Developing Countries}

There are five areas which all governments are required to base on in formulating policies to achieve compliance to disaster risk management; preparedness, risk identification, risk reduction, financial protection and resilient reconstruction (World Bank, 2014). Countries are required to invest in measures to facilitate the identification of disaster related risks by anticipating when they will occur to give ample time to local governments, businesses, communities and individuals to make informed decisions regarding mitigation measures. McDermott, (2016) further adds that Word Bank requires that every country formulates disaster risk management policies all aimed at reducing the extent of damage inflicted when they occur.

However, even though risk identification is critical to disaster management, the availability of resources and infrastructure to deal with the disaster when it occurs ascertains the effectiveness of the policies in place. Developing countries are particularly affected by this since most of the governments are cash-strapped hence limited budget allocation for risk identification initiatives. World Bank (2014) further adds that risk identification paves the way for implementing other policy areas since the information provided functions as the basis for formulating mitigation strategies. World Bank and the scholar seem to concur that significant effort on policies should be made on risk identification to enable respective governments to plan accordingly to minimize the level of damage inflicted on communities in disaster prone areas.

In Olu et. al., (2016) study to investigate ways of strengthening disaster management in Africa, the findings showed that inadequate financing of disaster management programmes is the biggest challenge to compliance to DRM policies. Olu et. al., further added that most developing countries as still developing hence prioritize available limited resources on critical issues such as fighting diseases, illiteracy and poverty. For this reason, they rely on donor aid to bridge the funding gap in disaster risk management. lloka, (2016) affirms Olu et. al.'s findings by arguing that disaster risk management is a capital-intensive engagement which causes developing counties to shy away from it since the economic costs are higher than the benefits.

Therefore, such governments employ passive measures of helping disaster victims to rebuild their lives as an economically viable option. Other studies have shown that there exist other challenges that curtail compliance to DRM policies including political instability, unpredictability of some disasters and lack of supportive infrastructure and expertise to mitigate influence of the disasters (Wilkinson, 2012; Jones, et. al., 2014 and Mall et. al., 2019). All the scholars concur that there exist challenges that negatively affect the ability to developing countries particularly in Africa co comply to DRM policies. However, they have not provided an assessment of the actual measurement of economic costs of complying with DRM policies with respect to the expected outcomes. That is, they only focused on the economic costs and benefits of being compliant while ignoring the social benefits associated with disaster risk management. Consequently, many studies have found that, while climate change has led increased incidence of flooding around the world, flooding in Nigeria is primarily caused by humans and exacerbated by humannature interactions. (Aderogba, 2012). The human-nature interactions are classified as follows: Poor or non-existent drainage infrastructure in most areas is a key human-induced exacerbation of Nigeria's flooding (Ogundele and Jegede 2011). In Nigeria, a large number of housing areas lack drainage systems, are built on flood plains, or rely on natural drainage systems. In some communities, it is normal practice to construct buildings and other infrastructure in such a way that they obstruct drainage channels (if any), resulting in flooding during the rainy season (Nabegu, 2014). Increasing urbanization has resulted in a greater proportion of ground surfaces being concreted, preventing water from percolating and preventing surface runoff. (Adeloye and Rustum 2011). One of the primary causes of flooding in urban areas is a lack of flood planning or drainage supply. As a result, there is a pressing need to develop and build drainage systems to address the flooding problem (Etuonovbe2011).

Another significant issue is the ineffective waste management system. One of the main causes contributing to, and exacerbating, the already severe flooding situation in most developing nations is poor waste management (with more emphasis on Nigeria) (Ojo and Adejugbagbe 2017). Citizens' negative attitudes about trash disposal have been widely explored in a number of researches (see Eneji et. al., 2016; Ojo and Adejugbagbe 2017; Olukanni, Adebayo, and Tenebe 2014; Sridhar and Ojediran 1983, among others). People were more likely to dump garbage on waterways due to a lack of suitable waste disposal systems, resulting in drainage obstructions and poor sanitation practices in densely populated metropolitan areas (Echendu, 2020). For example, a substantial fraction of the population engages in improper trash disposal practices such as roadside dumping, canal dumping, and dumping during rainstorms. During the rainy season, this causes waterways to get clogged, resulting in floods (Onwuemele, 2012). More so, city planning has a major effect on the social structure and leads to flooding. Consequently, in both developing and established nations, floods and urbanization are inextricably linked. (Echendu, 2020). Today, more than half of Nigerians reside in cities (Farrell, 2018). Flooding is more likely as a result of high urbanization rates without matching supply of urban infrastructure and facilities (Aderogba, 2012). Agricultural fields are also rapidly being converted to residential areas to meet housing demands 


\section{Flood Risk Management and its Compliance in Loko Community Adamawa State, Nigeria}

and development, which is done without adequate controls or drainage infrastructure, exacerbating the flooding problem (DanJumbo, Metzger, and Clark, 2018). Poor urban and regional planning and compounded by other numerous noncompliance issues; are one of the major causes of the floods in Nigeria (Echendu, 2020). As a result, Nigeria's floods are intimately connected to bad urban planning (Omoboye and Festus, 2014). Extendedly, where there is layout structural urban and regional planning, corruption and a lack of effective execution of planning rules make it impossible to build a viable FRM (Echendu, 2020). According to Nnaemeka-Okeke (2016), The present planning laws in Nigeria are conventional, but their development and implementation policies are inadequately monitored. Political involvement in city planning, understaffing, and a lack of functional equipment are all problems that impede good planning and the planners' ability to carry out their responsibilities (Nnaemeka-Okeke 2016; Oluwaseyi 2019). The licensing of development projects on natural floodplains and storm water channels is referred to as inadequate application of planning rules. This, in turn, exacerbates the flooding problem and has negative consequences for longterm sustainability (Nnaemeka-Okeke, 2016; Oluwaseyi 2019; and Echendu, 2020). Corruption is also a factor. Accepting bribes and ignoring concerns is a widespread practice among city planners. Approval for unlawful use of land, modification of approved building plans in regions that impede drains and natural waterways, and inadequate infrastructure development such as bridges that collapse during heavy rains are only a few examples of corrupt practices (Oladokun and Proverbs 2016).

Furthermore, residents take advantage of the weak development control gap and frequently extend their structures beyond the authorized limits, even going so far as to construct over drainage systems (Oladokun and Proverbs 2016). The non-implementation of the laws and corrupt activities of planning officials among others are incompatible with attaining long-term urban development. Poor planning and a lack of legal construction permissions are at the foundation of irresponsible developments, which have a wide range of effects (Adeloye and Rustum 2011).

For this reason, this study investigates compliance to FRM practices, the challenges, and stakeholder interventions to protect socio-economic wellbeing of Loko Community.

\section{STUDY AREA}

Loko is a settlement located on the southern bank of River Loko of Song Local Government Area (LGA) of Adamawa State (Figure 1). Lying on latitude $9^{\circ} 45^{\prime} \mathrm{N}$ and Longitude $12^{\circ} 36^{\prime} \mathrm{E}$. Loko basin is characterized by a broken relief of alternating hills and valleys (Tukur \& Ray, 1994) and occupies an area of about 55,000 hectares. Loko also lies on a relatively low elevation which has made it vulnerable to seasonal flooding.

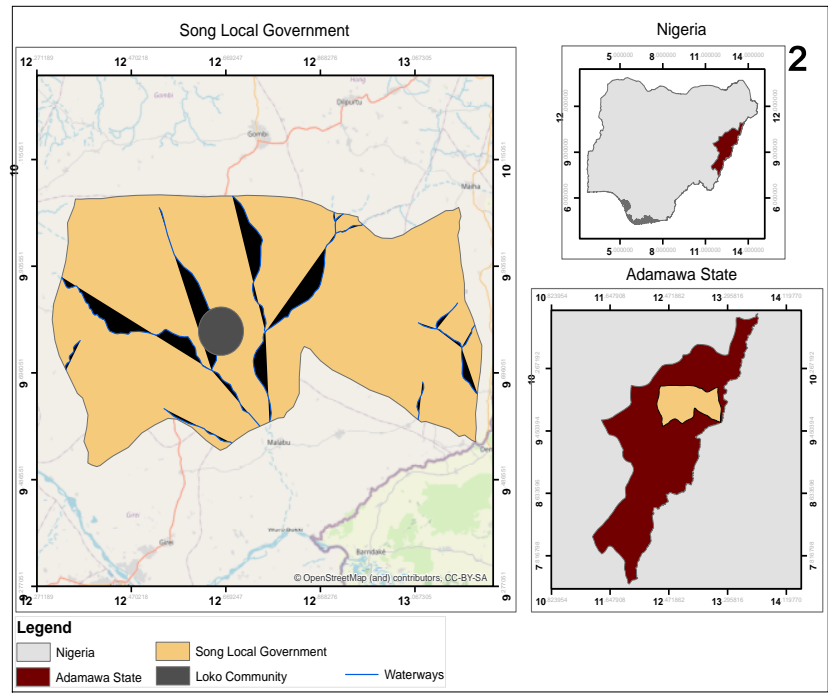

Figure 1: Location of Loko Community

Source: Author (2020)

\section{PROCEDURES, METHODS, AND MATERIALS}

Since the study was conducted in a single location; Loko community in Song Local Government Area, the whole research process was guided by the case study research design. Case study design is important to this study since it is comprehensive in that it allows the use of comprehensive tools/methods such as observations and interviews and reduces bias through adopting a diversity of perspectives (Alpi \& Evans, 2019). Data analysis took a descriptive approach, because of the research questions' nature. According to Wisdom \& Creswell (2013), integrating two or more research designs in a single study serves to validate the findings using qualitative and quantitative data sources. Therefore, the study aimed at finding information regarding the role of flood risk 


\section{Flood Risk Management and its Compliance in Loko Community Adamawa State, Nigeria}

administration in socio-demographic progress considering that the aspect of flood risk administration in Nigeria has been extensively studied with limited focus on socio-demographic progress.

The study tested the hypotheses that flood risk control is not effective in promoting socio-demographic progress in the Loko Community. All these hypotheses were tested to know whether they are true or not. Loko is a settlement located on the southern bank of River Loko of Song Local Government Area (LGA) of Adamawa State. Lying on latitude $9^{\circ} 45^{\prime} \mathrm{N}$ and Longitude $12^{\circ} 36^{\prime} \mathrm{E}$. Loko basin is characterized by a broken relief of alternating hills and valleys (Tukur \& Ray, 1994) and occupies an area of about 55,000 hectares. Loko also lies on a relatively low elevation which has made it vulnerable to seasonal flooding.

The target population for this study included residents of Loko community, staff of National Emergency Management Agency (NEMA) and staff of Adamawa State Emergency Management Agency (ADSEMA). Participants in this study were sampled from the target population of 4,200 inhabitants of Loko community, 20 NEMA staff and 48 ADSEMA staff. This figure constitutes the total number of staff in both agencies in Adamawa state.

A questionnaire, semi structured, with closed and open-ended Likert questions was the key instrument used for data collection. The instruments were administered using face-face administration for the participants, an approach associated with high response rate (Russell, 2006). After questionnaire retrieval, the principal researcher moderated focused group discussions in two groups namely, FGD 1 and FGD 2, comprising 13 and 12 participants, respectively. Key informant interviews was conducted as well, and professional information sought.

Quantitative data was cleaned, coded, entered and analysed using the Statistical Package for Social Sciences (SPSS) version 22. ANOVA test and descriptive statistics was used in analysing data in objective one in terms of frequencies and mean. Pearson correlation analysis was employed in objective three and ANOVA test, to assess the effectiveness of disaster risk control on sociodemographic progress. On the other hand, qualitative data was generated for the study from focus group discussions and structured questions. The qualitative data obtained from focus group discussions and key informant interviews were recorded using audio devices and later transcribed. The data collected and transcribed was labelled and anchor codes were assigned based on the research questions. Relevant statements from the participants were then coded putting under the respective anchor codes by using endnote function in Microsoft. Structure, magnitude, assessment, emotion, in vivo, and process coding were all employed in this study. The lists of the initial codes were compiled and grouped in their respective anchor codes. Frequency for each code was tallied. Categorization was generated from the codes. The study also examined the categorization, and generates themes which the study used in addressing the research questions. The data collected and transcribed was coded into the following themes; socio-demographic characteristics of persons living in areas prone to floods and the effect of flood on socio-demographic progress of the area.

\section{RESULTS AND DISCUSSIONS}

\section{A. Socio-Demographic Characteristics}

Male participants comprised the largest proportion of participants 194 (60.2\%) while females were $128(39.8 \%)$. These findings agreed with those of Watkins, Zimmermann and Poling, (2014) who found that, men are more willing to participate in communitybased studies based on the traditional roles where they are the heads of the family. This study also aligned with ASDSP's (2014) household hold survey results in Kisii County, which indicated that males made up $64 \%$ of households, while females and youth made up $11 \%$ and $26 \%$ of households, respectively. A significant portion of the respondents were between the ages of 28 and 37 years $148(45.9 \%)$, then those between 18 and 27 years 85 (25.8\%), and 38-47-year-olds 56 (17.4\%). Conversely, the least represented groups were those aged between $48-57$ years $23(7.1 \%)$ and those over 57 years were 10 representing $3.7 \%$ of the total sampled respondents. Although previous research had identified older people to be more knowledgeable (Rengalakshmi, 2002) and capable of providing more information on flood risk disaster management with a higher reliability rate, the input of younger community members was equally impactful and significant in assessing the role of flood risk administration for socioeconomic development.

\section{B. Level of Compliance to Flood Risk Administration Policies}

The result obtained on the level of compliance to flood risk administration as outlined in objective two presented in (Figure 2). 


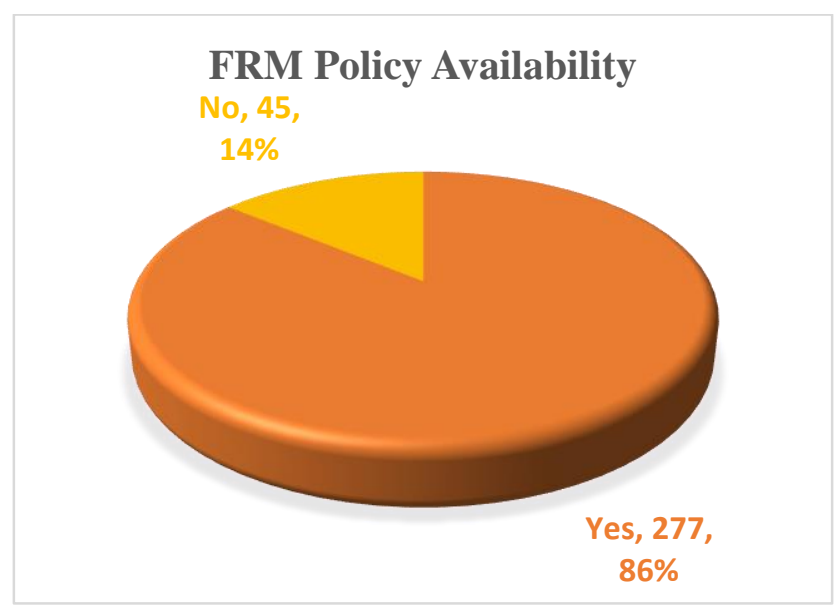

Fig 2: Graphical presentation on the level of agreement on Availability of Polices to guide FRM Source: Field Data (2020)

It was found that $86.0 \%$ (277) of participants showed high level of conformity that, there is high level of compliance to flood risk administration policies geared towards flood risk handling in the community while $14.0 \%$ (45) declined and submitted that, the level of compliance to flood risk handling in the community is low.

\section{Community engagement and Compliance to flood risk administration policies}

This study sought to understand community engagement and compliance to flood risk management policies. The community interviewees gave a number of reasons for and against effective compliance to flood risk administration policies. Most of the community members were of the view that the level of compliance to flood risk disaster management is high though further explained that some persons are stereotyped and compliance might be neglected for whatever reason based on the individual perception or attitudes towards warnings or personal orientation. As observed, socio-demographic characteristics of persons living in the flood prone area varies significantly from those living in non-flood areas of the Community. This could mean that some individuals living in the flood area are used to it and give little attention to any warning with the mind-set that, flooding is part of their life and there's nothing new about it.

Also, it was gathered that, majority of the community are enlightened and are willing to comply with the flood warning and other policy information. This could be due to active participation in discussions as well as support rendered by disaster management stakeholders from all over Nigeria which the impact is extended to Loko community of Adamawa state (United Nations Economic Commission for Africa, 2015) alongside the achievements of the National Plan of Action on Flood Disaster Risk Reduction which was prepared in 2006.This trend could be as a result of the tremendous effort observed by the community on the role flood risk administration played over time in terms of creating public awareness on the need for environmental best practices that focuses on sustainable development, provision of early warning flood systems, early preparation and displacement plans to ensure safety and provide food security.

\section{Challenges Experienced in complying with Flood Risk Management.}

In order to determine the level of compliance to flood risk administration, the study looked at some challenges experienced in complying with flood risk management. There are some constraints, which hinders full compliance to tackle various disasters especially flood in Nigeria; The most prevalent issue is a dispute between federal and state emergency response authorities about who has power at the location of an occurrence. The lack of decentralisation of function from federal to state causes significant inconsistencies and unnecessary systematic dysfunction (Osaghae,1992). To avoid future lawsuits and logger heads, this needs to be addressed correctly. The data was generated using open ended questionnaire and analysed descriptively using frequencies and percentages and presented in graph (Figure 3). 


\section{COMPLIANCE CHALLENGES}

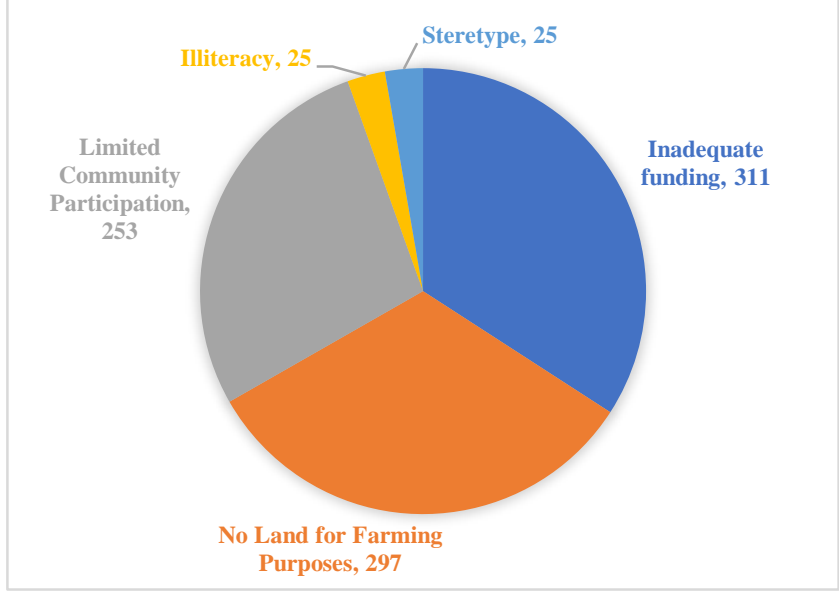

Figure 3: Graphical presentation of Data on Challenges Experienced in complying with FRM Polices

Source: Field Data (2020)

The results showed that, a very little proportion of participants $7.8 \%$ (25) indicated that, one of the challenges faced in complying to flood risk administration is inadequate funding, this appeared to be the least challenge as government made all necessary provisions in terms of funding to cater for disaster management especially flood in the area of interest. Moreover, 92.2\% (297) participants has no land for farming purposes as a vast majority depends on farming and animal rearing as sources of livelihood due to high unemployment rate. The findings further indicated that $78.6 \%$ (253) participants support the statement that, poor level of participation of community members poses a greater challenge to the level of compliance of flood risk administration. Illiteracy was identified as a minor constrain, since respondents who supported this viewpoint comprised 25 ( $7.8 \%$ ). Stereotypes were identified by $96.6 \%$ (311) of participants as a challenge faced in complying to flood risk administration as members of the communities are often stereotyped on roles to play in flood reduction based on gender, age, level of education and economic background. This limits the level of participation in environmental programmes and compliance to flood risk administration.

\section{E. Measures to Improve Flood Risk Management}

The study further assessed measures to improve the management of flood risk, as flood risk increases proportionally due to increases in vulnerability. The study finds that unless efforts and measures are put in place to reduce vulnerability and build capacity, flood disaster will continuously be on the increase in Loko community in Adamawa state Nigeria. Hence, to reduce vulnerability and improve adaptive capacity, sustainable measures need to be put in place and incorporated into national development policies.

Table 1: Distribution of measures to improve Flood Risk Management

\begin{tabular}{lcc}
\hline Responses & Frequency $(f)$ & Percentages (\%) \\
\hline Adequate machineries by the authority to enforce & 196 & 60.9 \\
compliance & & \\
There should be monitoring and evaluation & 55 & 17.1 \\
Periodic drainage clearing & 318 & 98.8 \\
Encourage community participation & 202 & 62.7 \\
Value reorientation & 23 & 7.14 \\
\hline
\end{tabular}

Source: Field Data (2020)

The result of the study showed that majority of the participants 196 (60.9\%) admitted that, in improving compliance to flood risk management, all NEMA sections across all governmental levels alongside other disaster management stakeholders must provide adequate machineries to enforce compliance. To achieve a reasonable level of compliance, the authority:

i. Must provide machineries to monitor and enforce compliance, supervise all FRM issues through the preparation and publications of FRM measures and strategies. 


\section{Flood Risk Management and its Compliance in Loko Community Adamawa State, Nigeria}

ii. Conduct surveys aimed at identifying key issues FRM requires, preparation and publication of FRM plans stating objectives that the authority intend to achieve.

iii. Provide and operate flood warning systems, extending and monitoring FRM works and watercourses, provide, install, operate, maintain apparatus required for effective monitoring of systems.

iv. Publish other relevant information concerning FRM, provide effective education and guidance relating to FRM core values (Flood Risk Management Act, 2013).

The data analyzed showed 55 (17.1\%) participants agreed that in improving compliance to flood risk administration, there should be monitoring and evaluation of flood risk administration policies. This is to ensure proper implementation FRM and assess extent of implementation without false assumptions. NEMA is responsible for monitoring the outcome of flood risk policies implementation to ascertain the extent to which FRM polices are working in disaster risk reduction through policies information, implementation and outcome (Yoe, 2014).

Also, in the study periodic clearing of drainages was identified by a vast majority of participants $318(98.8 \%)$ as a measure put in place to improve flood risk administration. Drainage systems have direct impact on functionality of flood mitigation structures and assessment of relationship between two systems has to be conducted in order to arrive at conclusion for operational principles and significance of FRM activities. Keeping water ways free from debris and solid waste and sanitation of drainages will reduce the effect of flood as blockages of drainage systems without periodic clearing in Loko community created a crucial sanitation problem for longer flooding period (Jochen, Evzen and Jiri, 2006) as observed in 2012.

The data collected and analyzed further identified community participation on table 4.6 item 4 as a measure to flood risk administration with 62.7\% participant. Because Integrated Flood Management (IFM) emphasizes collaborative responsibility of all stakeholders and the actual application of flood control measures, community engagement is critical at every stage of flood risk management, including preparedness, intervention, and socio-demographic recovery after disasters. IFM roles contributes in coordinating various community sub-groups, as it affects their interests and help to maximize benefits through agreement within community in order to gain from the available resources endowed in the environment (World Metrological Organization, 2008). The findings further identified value reorientation as a measure of improving flood risk administration with $7.14 \%$ participant conformed to the statement. Understanding the effect of environmental best practices as to what is wrong and right will help the community members participate in environmental best practices. For this reason, FRM indulges in creating value reorientation to further improve on level of compliance to flood risk administration.

Absence of collective value reorientation in a community often leads to individualized or household level practices motivated by necessity due to insufficient knowledge and awareness of community collective value orientation and its impact on their sources of livelihood. Such measures are ineffective and, over time, will be unable to safeguard the community and individual households from the negative impacts of floods. The efficacy, efficiency, needs, and practicability of policies and initiatives targeted at reducing flood disasters may be justified through community activities that focus on enhancing member involvement (APFM, 2004).

\section{F. Ways of improving adherence to FRM Policies}

Based on the key informant information, there is lack of enforcement and implementation of FRM policies aimed at ensuring sustainability, FRM policies needs review to cater for new trends and emerging issues and there is insufficient monitoring and succession of laid out FRM plans. Hence, NEMA, alongside other stakeholders in Nigeria, should ensure that all developed measures and strategies for managing flood disaster risks in the country are strictly adhere to.

However, key informant information indicates that, due to bureaucratic bottlenecks, the teaching of disaster risk reduction at those levels has yet to begin; the National Council on Education has not authorized the implementation of the revised curricula. The qualitative data gathered from key informants suggested that, government should exhibit some power to impose and enforce on the policy to ensure compliance to major actors of the policy and understand the problems of the policy through effective assessment and evaluation to make informed decisions on tackling same, there should be sanction on defaulting communities and vulnerability capacity assessment be carried out often.

The qualitative data gathered that, relevant stakeholders should take into cognizance the tripartite nature of the country that is, Federal, state and local governments and integrate all arms of government. There should be structural amendments to make the local arm more informed about risks, fine tune the already beautiful piece (the policy) and land tenure system in Nigeria should be used to enforce on the policy.

To test for statistical significance on level of compliance to flood risk administration, ANOVA test was applied and the results presented in table 4.7 revealed that at $95 \%$ confidence level, there was a statistical significance variation $p=0.000$ on the level of compliance to flood risk administration policies in Loko community, Adamawa state, Nigeria at degree of freedom 2, 13. Therefore 


\section{Flood Risk Management and its Compliance in Loko Community Adamawa State, Nigeria}

$\mathrm{H}_{02}$ which states that; there is no compliance to flood risk administration policies in Loko community, Adamawa state, Nigeria was accepted as $p=0.000<p=0.05$.

Table 2: ANOVA Test on Level of Compliance to Flood Risk Administration

\begin{tabular}{llccccc}
\hline Source of variation & df & Sum of Squares & MS & F & $\mathbf{F}_{0.05,2,13}$ & $\mathbf{P}$ \\
\hline Group & 2 & 32764.96 & 28905.4 & 2.39 & 3.89 & 0.05 \\
Error & 13 & 156658.24 & & & & \\
Total & 15 & 189423.2 & & & & \\
\hline
\end{tabular}

Source: Field Data (2020)

The level of compliance to flood risk administration was statistically determined through the critical value of rejection region $\mathrm{F}_{0.05,2,15}=3.89$, shows the $\mathrm{F}_{\text {statistics }}=2.39$ with a $p$-value $=0.05$. The null hypothesis was accepted, suggesting that there was no statistically significant variance in flood risk management compliance in Loko community, Adamawa state, Nigeria.

Because of ignorance, low environmental sustainability literacy, and superstitious beliefs such as rivers being viewed as deities who must be appeased when there is an outflow over river banks, drainage systems in many towns have been clogged with trash created by households. Scholars attributed non-compliance to policies of flood risk administration in most flood disaster prone areas in Nigeria to these factors. For instance, Oladokun and Proverbs (2016) observed that compliance to FRM is quite low in urban areas due to drainage blockages, improper planning and observable corruption among town planning officials. The findings in the work corroborates the findings in the study that blockage of drainage contribute to flood incidences. Similarly, Uzokwe (2015) also observes that poverty, ignorance and belief contributes to low level of compliance to FRM policies.

\section{CONCLUSIONS AND RECOMMENDATIONS}

\section{A. Summary}

Flood risk administration functions to reduce socio-demographic and human resources associated with disasters. Even though floods have their own benefits particularly in the agricultural sector, their associated consequences can result in significant sociodemographic losses that result in long-term negative impact on the affected community. In the last decade, there has been a major change in perspective in ways people attempt to cope with disasters from natural hazards. For this reason, there has been a lot of interest in assessing the effect of flood risk administration on socio-demographic progress in Loko community of Adamawa state, Nigeria.

The objective was to assess the compliance to FRM practices, determine associated challenges, identify stakeholder interventions to address the situation. The level of compliance to flood risk administration was assessed through quantitative and qualitative procedure using open ended questionnaire and key informant's toolkit. It was observed that majority 277 (86.0\%) of participants shows high level of conformity that, there is high level of compliance to flood risk administration policies geared towards flood risk alleviation, while 45 (14.0\%) decline and submitted that, the level of compliance to flood risk control in the area is quite low. Considering the effect that floods have on socio-economic progress of the area, there is a high level of compliance to flood risk control following the descriptive analysis on objective two. This could be due to direct participation in discussions and support rendered by disaster alleviation stakeholders all over Nigeria which the impact is extended to Loko community of Adamawa state. The study findings also revealed that NEMA and ADSEMA have put in place public enlightenment on flood risk administration as one of their major policies. This policy is effective with focus on environmental best practices that will promote flood risk reduction and impact.

According to the study findings, NEMA and ADSEMA had also increased community participation focusing on the participation in environmental programs with the aim of controlling possible flood risk through environmental sanitation, awareness through the activities of the government still remain at the federal and state level therefore intervention and compliance to policies at the local level becomes difficult but yet achievable. See section 4.3.8 for more detailed information.

Building capacity of stakeholders as part of flood risk administration significant role on socio economic development of Loko community in Adamawa state Nigeria. Based on the study findings, majority of participant 215 (66.8\%) attest that flood risk administration on socio-economic development in the area under study include building capacity of stakeholders in its activities of flood risk reduction while 85 (24.4\%) and only 22 (6.8\%) neither agreed nor disagreed with the aforementioned.

The result obtained further revealed that, majority 218 (67.7\%) of participants confirmed active involvement in flood risk handling on socio-demographic progress of Loko community in Adamawa state Nigeria while 49 (15.2\%) supported the views of the majority. Some 30 (9.3\%) neither agreed nor disagreed that stakeholders are active participants in flood risk handling in the 


\section{Flood Risk Management and its Compliance in Loko Community Adamawa State, Nigeria}

community under study. While another $2(0.6 \%)$ were of the opinion that conducting flood risk administration in respect to sociodemographic progress of Loko community does not actively involve all stakeholders in flood risk administration. However, responses in this regard increased as $23(7.1 \%)$ participants supported the aforementioned that there is no active participation of all stakeholders in flood risk administration.

\section{B. Conclusions}

In observing objective two of the study, the study findings demonstrated that in Loko community considering the effect of the floods on socio-economic progress of the area, there is a high level of compliance to flood risk administration. This was due to active participation in discussions and support rendered by disaster management stakeholders across the state. The study findings also indicated that the community is well enlightened on flood risk management as there is a well-structured mode of communication, flood Warning/Sensitization, Resettlement plans as well as drainage operations within the flood-prone areas. The study revealed that there were challenges in effective FRM. It shows that the challenges of flood risk administration in Loko community include: Inadequate Funding for flood risk administration, Poor Level of Community Participation, high Illiteracy levels within the community, and community Stereotypes.

As a means of coping with floods, communities should be encouraged to build dwellings out of durable materials and away from flood-prone areas. Furthermore, the Ministry of Agriculture and Cooperatives should encourage communities to increase the area cultivated on upland through Extension Services in order to improve household food security. A program of input assistance for disadvantaged but productive farmers should be proposed. It is necessary to create better and more suitable methods to prepare for and reduce the consequences of floods, as well as to include all stakeholders in order to improve communities' flood resilience.

\section{Recommendations}

The following are the recommendations based on the findings of this study on flood risk administration on socio-economic development in Loko community of Adamawa state, Nigeria.

i. The study calls for the creation of an informative and standardize database of the economic consequences of flooding to make progress on the understating of the wider economic impacts of flood risk. This will help inform the necessary bodies and help affected households, community to know the path to seek help or where they can get help. The study findings show that, the socio-demographic and economic status of the people are usually affected in time of flooding.

ii. There is need to promote community participation as it is crucial and necessary at every step of flood management, including flood preparation, response, and recovery. Through associated development initiatives, communities might attempt to optimize the advantages. Although the study observes that compliance to FRM is considerably high, the stereotyped people should be orientated and encouraged to appreciate the initiative.

iii. Involving the community in flood risk assessment, as well as planning and implementing risk management measures, is critical to the success of flood risk mitigation plans. As observed in the study findings, the gaps between the federal and state is huge as a result, there is a lack of engagement in local governance. These gaps should be closed up and form coordination to promote proper planning and implementation of the FRM.

\section{Suggestion for Further Research}

Due to the lively transition in flood risk management and the dynamism in the socio-economic interaction with climate change, what has been discovered is not exhaustive. The following suggestions for further research are based on this viewpoint.

i. This study was limited to assessing flood risk administration on socio-demographic progress in Loko community of Adamawa state, Nigeria. There is thus a need to carry out further research to determine the same process in a number of other communities in Nigeria to find out how flood risk administration affects their socio-demographic progress.

ii. More inclusive research should be conducted that will involve a bigger scope to establish whether flood risk handling has an impact on socio-economic development in Loko community of Adamawa state, Nigeria.

iii. To arrive at the above conclusions, this study used a case study research design. The structure, on the other hand, enables for observation of events in their natural contexts without the need for data processing. As a result, the researcher suggests that an experimental design be employed, with variables that can be controlled and quantified precisely, to reveal the impact of flood risk management on socio-economic advancement in Loko community.

iv. The community plays a great role in disaster risk handling. This is because, despite the use of similar disaster risk management methods in the same community setting, individual members of the community perform better than their colleagues in managing disasters. Therefore, it is necessary to determine the function of each community member in disaster risk management. 


\section{Flood Risk Management and its Compliance in Loko Community Adamawa State, Nigeria}

\section{ACKNOWLEDGEMENT}

Without the amazing support of my supervisors, Dr. F.L.M Minga'te and Dr. Samuel O. Ocholla, this work and the research underlying it would not have been feasible. Their passion, expertise, and meticulous attention to detail inspired me and helped keep my work on track. My friend and brother Yoksa Salmamza, went through my analysis and responded patiently, providing coloured photos of the charts and other vital information, I am grateful!

It is with immense satisfaction that I appreciate the efforts of my incredible spouse, Prince Ken Gabriel, who volunteered to read every portion of this article with a mixture of love and critique over several nights. The benevolence and knowledge of the essential contributors, have benefited this study in countless ways and protected me from making several mistakes; those that unavoidably remain are solely my fault.

\section{REFERENCES}

1) Ainehvand, S., Raeissi, P., Ravaghi, H., \& Maleki, M. (2019). Natural disasters and challenges toward achieving food security response in Iran. Journal of education and health promotion, 8.

2) Aja, G. N., and A. Y. Olaore. 2014. "The Impact of Flooding on the Social Determinants of Health in Nigeria: A Case for North-South Institutional Collaboration to Address Climate Issues." Developing Country Studies 4 (22): 6-12.

3) Alpi, K. M., \& Evans, J. J. (2019). Distinguishing case study as a research method from case reports as a publication type. Journal of the Medical Library Association: JMLA, 107(1), 1.

4) Idris, S., \& Dharmasiri, L. M. (2015). Flood risk inevitability and flood risk management in urban areas: A review. Journal of geography and Regional Planning, 8(8), 205-209.

5) Iloka, N. G. (2016). Indigenous knowledge for disaster risk reduction: An African perspective. Jàmbá: Journal of Disaster Risk Studies, 8(1).

6) Jones, S., Oven, K. J., Manyena, B., \& Aryal, K. (2014). Governance struggles and policy processes in disaster risk reduction: A case study from Nepal. Geoforum, 57, 78-90.

7) Kenny, S. (2016). Community development today: engaging challenges through cosmopolitanism. Community Development Journal, 51(1), 23-41.

8) Lal, P. N., Lal, P. N., Singh, R., \& Holland, P. (2009). Relationship between natural disasters and poverty: a Fiji case study. SOPAC.

9) Loayza, N. V., Olaberria, E., Rigolini, J., \& Christiaensen, L. (2012). Natural disasters and growth: Going beyond the averages. World Development, 40(7), 1317-1336.

10) Ludwig, F., C. T. Van Scheltinga, J. Verhagen, B. Kruijt, E. vanlerland, R. Dellink, . . P. Kabat. 2007. Climate Changelmpacts on Developing countries-EU Accountability.Wageningen University and Research Centre.

11) Mall, R. K., Srivastava, R. K., Banerjee, T., Mishra, O. P., Bhatt, D., \& Sonkar, G. (2019). Disaster risk reduction including climate change adaptation over south Asia: challenges and ways forward. International Journal of Disaster Risk Science, 10(1), 14-27.

12) Mata-Lima, H., Alvino-Borba, A., Pinheiro, A., Mata-Lima, A., \& Almeida, J. A. (2013). Impacts of natural disasters on environmental and socio-economic systems: What makes the difference? Ambiente \& Sociedade, 16(3), 45-64.

13) McDermott, T. K. (2016). Investing in disaster risk management in an uncertain climate. The World Bank.

14) Morrison, A., Westbrook, C. J., \& Noble, B. F. (2018). A review of the flood risk management governance and resilience literature. Journal of Flood Risk Management, 11(3), 291-304.

15) NEMA, (2013). Report on flood disasters in Nigeria. Abuja: Government Press.

16) NEMA, (2014). Nigeria: National progress report on the implementation of the Hyogo Framework for Action (2013-2015) - Interim. Abuja: Government Press.

17) Oladokun, V. and Proverbs, D. (2016). Flood risk management in Nigeria: a review of the challenges and opportunities. International Journal of Safety and Security Engineering 6 (3).

18) Olanrewaju, C. C., Chitakira, M., Olanrewaju, O. A., \&Louw, E. (2019). Impacts of flood disasters in Nigeria: A critical evaluation of health implications and management. Jàmbá: Journal of Disaster Risk Studies, 11(1), 1-9.

19) Olu, O., Usman, A., Manga, L., Anyangwe, S., Kalambay, K., Nsenga, N., ... \& Benson, A. (2016). Strengthening health disaster risk management in Africa: multi-sectoral and people-centred approaches are required in the post-Hyogo Framework of Action era. BMC public health, 16(1), 691.

20) Osaghae, E. (1992). The Status of State Governments in Nigeria's Federalism. Publius, 22(3), 181-200. Retrieved November 20, 2020, from http://www.jstor.org/stable/3330259 


\section{Flood Risk Management and its Compliance in Loko Community Adamawa State, Nigeria}

21) Tirivangasi, H. M. (2018). Regional disaster risk management strategies for food security: Probing Southern African Development Community channels for influencing national policy. Jàmbá: Journal of Disaster Risk Studies, 10(1), 1-7.

22) Van Niekerk, D. (2015). Disaster risk governance in Africa: A retrospective assessment of progress against the Hyogo Framework for Action (2000-2012). Disaster Prevention and Management, 24(3), 397-416.

23) Wilkinson, E. (2012). Transforming disaster risk management: a political economy approach. ODI, London.

24) Wisdom, J., \& Creswell, J.W. (2013). Mixed method: integrating quantitative and qualitative data collection and analysis while studying patient-centred medical home models. Rockville: Agency for healthcare research and quality.

25) World Bank. (2017). Strengthening Environmental Management and Reducing Degradation in Peru. Retrieved 2 September 2019, from https://www.worldbank.org/en/results/2017/04/04/strengthening-environmental-managementreducing-degradation-peru

26) Zimmerman, M. A. (2000). Empowerment theory. In Handbook of community psychology (pp. 43-63). Springer, Boston, MA. 